\title{
Perspectives on India-Bangladesh Water Dispute: The Farakka Barrage
}

\author{
Rajkumar Singh ${ }^{1}$ \\ ${ }^{\prime}$ Department of Political Science, BNMU, West Campus, P.G. Centre, Saharsa-852201 (Bihar), India. \\ Email: rajkumarsinghpg@yahoo.com
}

\begin{abstract}
The holy waters of Ganga have proved despair rather than a hope in relations between India and Bangladesh. It was after the initial differences in regard to the construction of Farakka barrage between India and Pakistan that the former had taken almost a unilateral decision to construct a barrage, in particular, to save the port of Calcutta from excess silting. Years after the independence of Bangladesh commissioning of the barrage took place and that was the starting point of a series of bilateral negotiations/agreements to determine the share of water that each side was to receive during the lean season of every year. In the start IndoBangladesh relations was marked as honeymoon phase of their relationship with no differing perceptions in sight. However it all took a ' $U$ ' turn when Sheikh Mujib was assassinated in August 1975 and a series of coup reigned in Bangladesh one after another. At a later stage the sharing of waters at Farakka had become more a matter of politics than of economy as the change over suited the military Generals of Bangladesh, who, apart from all, faced the problem of legitimacy. Difference of social, political, economic and religious bases in India and Bangladesh has added fuel to the fire and the waters of Farakka was paraded before the world community as the most blatant example of India's "intransigence" against a weak and small neighbour. In between the relationship of love and hate the two had signed three agreements on the sharing of Ganga Waters at Farakka respectively in 1975, 1977 and 1996. The paper aims to examine the different aspects of the two sides and mutual understanding thereupon. The study is beneficial for the countries of the region and outside to keep the fight between bordering neighbours away and help promote regional / global peace in the larger interest of humanity.
\end{abstract}

Keywords: India, Bangladesh, Socio-economic condition, Agreements and prospect.

Licensed: This work is licensed under a Creative Commons Attribution 4.0 License.

\section{Initial Developments}

In pre and post independence phase the issue of constructing a barrage across the river Ganga at Farakka was alive and drew the attention of the people then in power. Continuous efforts were undertaken and committees of experts were appointed from time to time to formulate measures, to maintain uninterrupted navigation on Hooghly waterway. Opinions on the issue were sought by a large number of engineers of world repute like Stevenson Moore in 1919, Sir William Willcock in 1930, T.M. Oag in 1939 and A. Webster in 1946. At the time of partition Sir Cyril Radcliff, the chairman of the Bengal Boundary Commission, who was authorised to demarcate boundary between India and Pakistan, realised the importance of Farakka and saw to it that the entire Bhagirathi-Hooghly the off take from Ganga was given to India as it was a must for the existence of Calcutta city and the port. Keeping it in view, the Boundary Commission demarcated the district of Murshidabad, which was predominantly a Muslim majority area in India, and in lieu awarded the region of Khulua, which was a Hindu dominated, to Pakistan. 
In post-independence phase Dr. Walter Henson of Germany was first and final to suggest, in 1957, that proposal for the construction of a barrage across the Ganga was the best solution of this technical problem. It was the most purposeful measure with which the long term deterioration in Bhagirathi-Hooghly could be stopped and could possibly be converted into a gradual improvement (Dixit, 1969). Earlier a detailed report of Calcutta port prepared by Hydraulics Study Department of the port in 1957 was handed over to Dr. Henson in which it was said that in the monsoon season considerable volume of sand are brought down to the various bars and crossing the Hooghly and with the increase in the monsoon flows practical only with the sharp peaks, the river channel established by dredging during the dry season is disturbed. It also pointed out that the study improvement in depths over the bars and crossing occur when there are prolonged head water supply (Foreign Affairs Record, 1977). The suggestion of Dr. Walter was based on this exhaustive report.

\section{Early Status of India}

Construction of a barrage at Farakka across the river Ganga was necessitated more from India's point of view that forced New Delhi to take a lead in its planning and execution. Ten million tonnes of silt entered the river every year from the sea with high tides. The monsoon floods in Hooghly flashes 6 million tonnes of silt back to the sea leaving behind an accumulating balance of 4 million tonnes every year which was slowly but regularly choking sections of the river. Massive dredging operations had been undertaken from time to time to keep the shipping channel clear. Calcutta port authorities were spending Rs. 75 lakhs per year preceding the year 1972 for dredging but in 1972 the expenditure went up to Rs. 10 crores : yet the silting continues unabated. The 126 miles voyage between Calcutta port and the estuary through the river Hooghly took as much as 26 hours because the ship had to wait at three points enroute for the high tide to cross the shallow points.

Calcutta is an important Indian port situated on the bank of the river Hooghly. The port is situated 126 miles away from the sea. It is through this Hooghly water way that ships of all states have to pass to reach Calcutta port and it is sustained by the supply of water from Ganga. After flood of an unprecedented magnitude in the year 1789, it abruptly changed its course and carved out the present day channel known as Padma that flows into Bangladesh territory. The upper reaches of its former channel became a distributary and consequently began to silt up, reducing the number of days in the year in which large vessel can use the port at a greater inland distance (Vaishnav, 1975).

Thus, the main objective of Farakka Barrage Project was the improvement of Calcutta port, and for the fresh water supply from Hooghly to adjoining industrial complex. The silt makes it impossible for the ships to reach Calcutta port throughout the year because there has been fast deterioration of sailing opportunities. In January 1957 the maximum drafts were 27 feet; in January 1959 the drafts fell to 24 feet (Bains, 1962). The number of sailing opportunities has also been seriously affected. In 1938 ships of draught of 26 feet could use the port nearly 300 days a year, now such vessels could not use the port at all. The resulting decline in traffic handled by the port had been drastic. The port handled 11 million tonnes of traffic in 1964-65 but it declined to 7.5 million tonnes in 1974-75. The decline took place despite rapid industrialisation of the hinterland since India's independence in 1947. The deterioration of the Bhagirathi-Hooghly and consequent decline of the Calcutta port affected the health sanitation and economic life of the people not just on the banks of the river but a vast area of land historically dependent directly or indirectly on the river .

Apart from decline in traffic and deterioration in sailing opportunities, the Government of India viewed the interests of the population of Calcutta city which was much more than the population of Bangladesh. Indeed, the rational of saving Calcutta city and the port impinges upon the economy of as many as 13 states of India as well as the neighbouring countries Nepal and Bhutan.

The industrial and commercial activities located in the area cover some of the most vital sectors of the Indian economy including minerals and metals, transport machinery, steel, textile, tea, jute, food processing and leather industries. The utilisation of Ganga waters by India for such vital purpose, affecting the life of a large segment of the Indian society could by no stretch of imagination be characterised as wasteful.

\section{Pakistani Status}

Pakistan had, since the beginning of the plan, been opposing the construction of a barrage across the river Ganga at Farakka mainly on the ground that execution of the project would reduce East Pakistan's supply of water, deprive it of its share of water and further development. It also put forward seven points in favour of its argument for not constructing the barrage as it would cast an adverse effect on the overall development of its Eastern part (Financial Express, 1977). India, on the other hand, had repeatedly assured Pakistan that Farakka barrage scheme would not disturb the irrigation scheme of East Pakistan for the metrological conditions of East Pakistan were such that there was generally an excess of water and the problem was how to drain it away. Pakistan had also charged India that latter's approach to the issue had been contrary to international law and practice. S. Pirzada, the Foreign Minister of Pakistan, in reply to a question in Pakistan's National Assembly, declared on 18 July 1967 that the waters of the river Ganga should be equitably be shared by the two countries on the basis of genuine needs and in accordance with international law. 
Despite differences between the two over the construction and purpose of the barrage, delegations of India and Pakistan met several time to resolve the issue. Four meetings of the experts of the two countries were held between July 1960 and January 1962 but failed to break the deadlock. In March 1961 when Jawaharlal Nehru, the then Prime Minister of India, and Ayub Khan, the President of Pakistan discussed the issue at the Commonwealth Conference of Prime Ministers, in London, the two dignitaries seemed poles apart. While Nehru assured Ayub Khan of a reasonable settlement, the latter had suggested to refer the matter to the technical experts (Alva, 1979). Pakistan had also repeated its suggestion in July 1961, in mid 1962, in May 1963 and in June 1965, but the Government of India, in its reply, maintained that ministerial conference could only be held after the exchange of data regarding the project.

With a view to put pressure on New Delhi Islamabad tried to internationalise the issue by raising it at the International Water For Peace Conference, held in Washington, in May 1967. Again in 1968 it was raised at the Afro-Asian Legal Consultative Committee meeting held in Bangkok. The year also witnessed bilateral talks between the two in the second week of May in which Indian side explained how the barrage would help East Pakistan in overcoming recurring flood menace (Lok Sabha Debates, 1977). However, it rejected the Pakistani delegation's suggestion that good offices of a third party like the World Bank should be used to resolve their differences over the utilisation of the water of the eastern rivers.

Nothing concrete came out from the several round of talks that were held between India and Pakistan in 1969-70. Probably the domestic setting of Pakistan was not favourable during the 1968 to 1970 talks. It was during this period that President Ayub Khan had stepped down and Yahya Khan had taken the charge of the office. A movement in East Pakistan for autonomy had already been launched by the National Awami League Party. By raising unwarranted objections during the talks, the Government of Pakistan wanted to show that how much serious it was in resolving the crisis. It was, probably, an act to counter the autonomy movement and divert the attention of the opposition parties. The sincerity of Pakistan itself was not without doubt.

\section{Emergence of Bangladesh}

The most crucial determinant of any policy, whether domestic or foreign, is the people constituting a nation, whose attitude reflecting the extent of their socio-economic and cultural development play a significant role in all policy matters (Arbatov, 1973). Bangladesh is a geographical integrate of the subcontinent earlier known as Indo-Pakistan sub-continent. What formerly was a nation state as part of the big continent of Asia, became a sub-continent when the nation was partitioned forming two nations-India and Pakistan in August 1947. Bangladesh is a geographical unit of the sub-continent which before 1947 was one nation state. Apart from common inheritance in terms of culture, tradition and socio-economic and political legacies, the countries of the sub-continent have many more things in common than irritants among them. Even then irritants have had the upper hand and what was once a single nation state, has fallen apart divided into at least three independent nation states (Narain, 1987). The physical proximity of Bangladesh with India and other neighbours is an important factor which at once, is viewed as the cause of irritation and a possibility of amicability between the two countries.

In comparison to West Pakistan, the socio economic structure of Bangladesh at the time of independence was in a advance stage because feudal relations had already made rooms for semi-feudal, semi-capitalist relations. The Hindus and the Muslims constituted two distinct sections of population in Bangladesh. There are social and religious differences between them. Yet, close association and system of fictive kinship have brought them in close contact with each other. It kept the nationalist ideology in the political culture of Bangladesh intact more or less before its independence in December 1971. As it was strong enough in its base, the separate ethno-cultural entity of Bengalis had contributed to the forming of political culture, particularly during the colonial days. After 1947 the idea of a distinct national group received political validity and was intensified by two leading events : the language movement of 1952 and the Six Point Programme of 1966 (Chakravarti, 1978). The next remarkable phase in the Politics of Bangladesh was the period 1947-71 which witnessed solidification of this nationalism, Thus India commenced its relations in 1971 with a mature country from the view point of nationality.

In 1947, the Eastern Pakistan was economically stronger than its Western part but as latter's discriminatory policy continued in each and every sphere of economy, it lagged far behind the pace of development in united Pakistan. During two and a half decades of being part of Pakistan, Bangladesh was exploited by West Pakistanis almost in the same fashion, as had been by the British. The continued economic disparity finally brought forth the concept of two-economy to the forefront. The two-economy thesis was propounded by some East Pakistani economists and rested primarily on two points : first, because of its geographical peculiarity. Pakistan did in fact have two separate and distinct economy; and second, the economic policy of the Government of Pakistan always worked against the interest of East Pakistan and gave rise to economic disparity between the two wings of Pakistan.

Thus, the creation of Pakistan seriously damaged trade and economic activity in the eastern region and East Bengal was the worst sufferer. Bangladesh, in terms of national resources, is not such as to develop selfreliant economy. It has jute and natural gas. In terms of minerals it is very poor. For coal and iron it is thoroughly dependent on others. There is not much scope for hydro-electric power, as mostly the region is 
flat, despite huge availability of water. The disrupted economy and the resultant chaos in East Bengal was one of the factors behind the demand for autonomy and subsequently the clamour for independence.

As a result of the differing perceptions in socio-economic sphere the purely bilateral problem of sharing the Ganga waters at Farakka was sought to be internationalised and attempts were made, though not very successfully, to malign India in every possible way. Backed by the call of jehad, against the "ungrateful Hindus" who were accused of not having accepted the sovereignty of Bangladesh over the distribution of Ganga waters, the Government of Bangladesh sought to make the Farakka issue a communal one. In the postMujib phase of Indo-Bangladesh relations, the new government did nothing to curb anti-Indian tirade in the communal press in Bangladesh. The supporters of the new regime sought to link the Farakka issue with general accusations against India and called for eliminating the last of the national traitors and their agents and for this they resolved to "stand by the armed forces". Surprisingly, technical aspects and the problem of recurring floods due to uncontrolled river waters were side tracked and, instead, the so-called threat of India's aggression was projected at various international fora.

Apart from the religious affinity of the people of Bangladesh, the fact that they lived as citizens of Pakistan for over 24 years during which religion used to play a vital role in both the domestic and foreign affairs of the country had become one of the most important factors in the image formation of the people (Bari, 1975). This image was negative one, and nurtured on the basis of the so-called fundamental difference between 'Muslim Pakistan and Hindu India'. The legacy of this long association with Pakistan remained in future an important aspect which has a definite bearing on Indo-Bangladesh relations.

Despite the fact that religion is very close to one's being, it has neither been a factor to unite diverse communities nor it has been a sole factor to create politically sovereign identities out of one social community. Though the first division of the Indian sub-continent was made on the basis of religion, substantial religious minorities remained in both the newly created nations India and Pakistan. In India the leaders of national liberation movement had recognised the concept of unity in diversity and tried to carry forward the movement on secular lines. They were opposed to communal demand for the creation of Pakistan and denied the twonation theory which was being proposed by the British colonialists.

Perhaps on being influenced from India, the national liberation movement in Bangladesh threw off the mask of religion and sought to unite the people with the aim of defending Bengali nationalism, language and culture. In this movement, the humanitarian role played by India, in contrast to the ghastly crimes perpetrated by the West Pakistani military rulers, brought the people of Bangladesh nearer to their Indian brethren into a bond of cordiality and friendship. During the entire period of liberation movement religion did not play even the minimal progressive role, as it had already proved its futility in keeping Pakistan united. Reintroduction of religion after the liberation of Bangladesh, as a political tool, was, therefore, not in tune with the objectives of national liberation movement.

\section{Responses of Bangladesh}

Expressing total solidarity with the principles and objectives of the national liberation movement the first Government of Sheikh Mujibur Rahman, in its historic constitution of 1972 included nationalism democracy secularism and socialism. However, the later developments on the issue made it clear that the secular principle of Bangladesh was planted on a religious society where still people were not in favour of discarding it. Religion was too sacred a trust with the people, which could not be allowed to be polluted by political considerations. Unfortunately people failed to understand that Bangladesh had emerged as a secular state, not because the religion of the vast majority of the people was in danger, but to ensure fuller manifestation of its secular values like language and culture in the context of socio-economic development, free from foreign exploitation. Bangladesh's survival as an Islamic state kept it away from India and put nearer to powers, friendly neither to India nor to Bangladesh.

The Bangladesh war of independence was fought under the leadership of Awami League who shared almost the same framework of social philosophy as the Indian ruling party of the time. The mixture of a rather populist version of socialism with reformist vision of state capitalism, and an ideological adherence to the principle of secular and democratic state brought India under the Congress and Bangladesh under the Awami League within the same general framework of state ideology (Uyangoda, 1999). The perceived mutuality of interests between India and Bangladesh took concrete shape during 1971-1975 or till Sheikh Mujibur Rahman was all in all at the helm of affairs. The Post-Mujib period of Bangladesh nourished a strong anti-India feeling which became violent and did not spare even the bilateral issues, such as, the sharing of Ganga waters at Farakka. Keeping in view the geopolitical terms and also because of India's role in Bangladesh's national liberation movement it was a difficult task for any government in the country to go whole hog against India, nevertheless the fact remains that both, at the government level and with its abetment at the level of media serious attempts were made to undermine friendly relations with India.

However, this difficult task was made easy by the post-1975 regimes of Bangladesh. The new rulers had anti-Indians' as one of its plank, and they immediately embarked upon an anti-Indian tirade. They used irritants not unusual between neighbouring countries as bases for their campaign and used every national and international forum to defame India. Dhaka's failure to make a point at the Colombo Summit of non-aligned 
nations was paraded as a success and India's just criticism of Bangladesh's attempts to internationalise Farakka issue was branded as an exhibition of frustration, disillusionment and defeat at the Colombo meet (Saturday, 1976). War hysteria was sought to be created in Bangladesh in which the then ruler Ziaur-Rahman was next to none and said, 'We are concerned about the aggression being carried out from across the border and also about the deliberate withdrawal of huge quantum of water from the Ganga to the detriments of Bangladesh. We will face up these aggressions at all costs and shall stand up heads erect in full glory of a free nation. Each one of us shall fight arm in hand, if need be'(Bangladesh Observer, 1976).

The anti-India tirade in the post-Mujib phase had a definite national as well as international support. Ruler's new plank was fully backed by the communal political parties, which had been rehabilitated after the coup. The ultra-leftists and pro-Beijing elements were also not lagging behind in supporting Zia's Government. The military rulers of Bangladesh while embarked upon India for latter's hegemonic ambitions, they, as a balancing act, sought to improve country's relations with China. It is significant to note here that Beijing, along with Washington, was the instigator of the conspiracy that overthrew Sheikh Mujibur Rahman. In the changed circumstances both China and the US became the champion of Bangladesh's inalienable rights vis-a-vis India. Two goodwill delegations from Bangladesh visited China in May and June 1976 and Peking had officially condemned the Indian attitude towards Bangladesh on the Ganges river waters and border disputes. China gave full support to Bangladesh on the Farakka issue at the UN.

It was clear from the perception and attitude of the new rulers of Bangladesh that they formed the anti Indian policies in total disregard of the ground realities, prevailed in relations between the two countries. Failure of Bangladesh effort to carry the Farakka issue at Colombo and the UN, established the fact that the problems between the two countries could not be resolved on the crest of communal propaganda, and that to talk of war and military preparedness to face Indian transigence was, to say the least unrealistic. Having realised the disappointments, in the beginning of the year 1977 Bangladesh agreed to talk on the issue with India that made substantial agreements to be signed possible on the sharing of Ganga waters between India and Bangladesh.

\section{Concluded Agreements on Farakka}

After the independence of Bangladesh a major breakthrough came in the relations of the two countries when they signed a Treaty of Friendship, Cooperation and Peace during Indira Gandhi's visit to Dhaka in March 1972. Article VI of the Treaty maintained that the high contracting parties further agreed to make a joint study and take joint action in the fields of flood control, river basin development and the development of hydro-electric power and irrigation. The discussions of the two Prime Ministers on sharing of the waters of Ganga at Dhaka resulted in the formation of a Joint Rivers Commission (JRC) relating to which, statutes were signed in Dhaka on 24 November 1972. The JRC was entrusted with the task of discussing at length the approach to long term planning for development of the water resources of the Ganga and other river systems.

As a follow up of the good understanding between India and Bangladesh, the two had signed an Interim Agreement on the sharing of Ganga waters at Farakka on 18 April 1975. The Agreement came at the end of three-day negotiations between Jagjivan Ram, the Agriculture Minister of India, and his Bangladeshi counterpart Abdur Rub Sernibat. Under the agreement signed in Dhaka India was allowed to draw up to a specific volume of water for its feeder canal for the benefit of Calcutta port. The daily withdrawal of water ranged between 11,000 and 16,000 cusecs in the last ten days of April and May respectively. The remaining flow of water was allowed to go to Bangladesh.

Despite several lackings, the agreement was welcomed by most of the leading newspapers as it set an outstanding example of mutual understanding and accommodation (Lok Sabha Debates, 1975). The port of Calcutta required 40,000 cusecs of water throughout the year including the lean months, which was necessary to flush the silt up Hooghly. Secondly, there was no time limit in the agreement. It would have been better if some time limit would have been fixed. Thirdly, during the lean season heavy withdrawals would reduce the share of Padma in Bangladesh. But it is significant to mention here that it was done on an adhoc basis. Jagjivan Ram, a signatory of the agreement and India's Minister for Agriculture, in a statement in the Loksabha on 21 May 1975, maintained, ; Since the discussion regarding the allocation of the minimum flow of Ganga during the lean months are continuing between the two governments the present agreement is a provisional assignment to enable the running of the feeder canal.' Lack of any agreement for the lean season flow of Ganga at Farakka made Bangladesh anxious more than that of India and therefore, it raised the issue at different international fora.

The Second Agreement on the sharing of Ganga waters at Farakka was signed on 5 November 1977 when a non-Congress government under the premiership of Morarji Desai had taken over in India. With the change of guard at New Delhi, a climate of mutual understanding and cooperation created that paved the way for such an exhaustive and liberal agreement between the two countries. The signed agreement contained fifteen articles divided into three parts. The first part covered Articles I-VII and dealt with the terms and conditions of the sharing of Ganges waters during the lean season. Article II of the agreement provided for the sharing of waters from 1 st January to 31 st of May every year which was to depend on the actual availability of waters at the barrage. It also gave a guarantee to Bangladesh of $80 \%$ of its share for ten days 21-30 April, every year. 
Articles IV-VII were related to the setting up of joint committees of the representatives nominated by the two governments to observe and record the daily flow below the Farakka barrage and in the Feeder Canal as well as at Hardinge Bridge. The Committee was to be responsible for supervising the implementation of the shortterm aspects of the agreement relating to the division of the available waters during the lean season (The Hindu, 1977). According to part II of the agreement the Joint Rivers Commission was reactivated with a view to finding a long term solution of the problem. The third part (Articles XII-XV) dealt with the provisions of review and duration of the Agreement.

Prime Minister Morarji Desai and Atal Bihari Vajpayee, the Minister for External Affairs, made an official statement in the Loksabha and Rajyasabha respectively on 14 November 1977 in which they maintained that the agreement had to be based on the principles of shared sacrifices and mutual accommodation without affecting the right and entitlement of either country during the lean season when there was not enough water to meet the requirement of both the countries. Among other things, the statement also noted the Government of India's hope that the approach and spirit which made the agreement possible, if applied to larger spectrum of country's relations with Bangladesh, should lead to an ever-widening cooperation between the two countries. But as the good wishes of the new Janata Government was not sufficient to fulfil the needs of Calcutta port, the agreement drew critical references in both the Houses particularly from the members of West Bengal. They termed the agreement as "nothing but an apologia for a political agreement entered into with the intention of appeasing a military regime’. They called the agreement a sell out for political purposes in which the interests of the port of Calcutta had been compromised (Lok Sabha Debates, 1977).

The Third and the latest agreement on the sharing of Ganga waters at Farakka was also signed during the reign of a non-Congress government on 12 December 1996. It was signed by Sheikh Hasina, the Prime Minister of Bangladesh, and her Indian counterpart H.D. Devegowda, who headed the government of a United Front. The treaty will be valid for 30 years with provision of review after every five years or earlier. The signed treaty provided that if the availability of water at Farakka is 70,000 cusecs or less, it will be shared between the two on 50-50 basis. If the quantum is between 70,000 and 75,000 cusecs, Bangladesh will get 35,000 cusecs while India will retain the rest. If the quantum rises above 75,000 cusecs, India will retain 40,000 cusecs, while the rest will go to Bangladesh. The lean period for both the countries starts in the first week of January and lasts 150 days. But the leanest period is between the middle of March to the first week of May. In addition, the 10-day hydraulic cycles giving the advantage to India and Bangladesh alternately, ensures that neither side will face a crisis during the period (Indian Recorder, 1997).

The agreement of December 1996 on the sharing of Ganga waters at Farakka is for the longest period ever signed by the two countries. Jyoti Basu, played a very active and positive role in the negotiations and provisions have been made to take care that neither Bangladesh nor India or more precisely West Bengal is at a disadvantage. It was welcomed in New Delhi and Dhaka where both sides expressed satisfaction over signing of the treaty. Because the new government of Bangladesh is not committed to an anti-Indian programme, they seized the opportunity to begin a new chapter in India-Bangladesh relations. They put the relations on a stronger basis and hoped it to be so in future.

\section{Conclusions and Cautions}

In the start Indo-Bangladesh relations was marked as honeymoon phase of their relationship with no differing perceptions in sight. However, it all took a 'U' turn when Sheikh Mujib was assassinated in August 1975 and a series of coup reigned in Bangladesh one after another. At a later stage the sharing of waters at Farakka had become more a matter of politics than of economy as the change over suited the military General of Bangladesh, who, apart from all, faced the problem of legitimacy. Although India and Bangladesh share 54 trans-boundary rivers, big and small, the major area of dispute has been India's construction and operation of the Farakka Barrage. The aim of construction of the Farakka Barrage was to increase the lean period flow of the Bhagirathi Hooghly branch of Ganga to increase the water depth at Kolkata port which was threatened by siltation. Later as irrigation withdrawals increased in Bangladesh, dispute arose between India and Bangladesh over the sharing of the lean season flow at Farakka. The inadequacy of water during the lean season to meet the assessed demands in the two countries is the root cause of the conflict.

Even after three Agreements made so far in 1975, 1977 and 1996 on the division of water between India and Bangladesh during lean season the Bangladesh government feels that the reduction in flow caused damage to agriculture, industry and ecology in the basin in Bangladesh. Because of the inability of the concerned governments to come to any lasting agreement over in last decades on sharing the river water, this problem has grown and now it is also viewed as a case of upstream-downstream dispute. On the other India is committed to carry forward the mission of strengthening the historic bonds and impart a vision for the future that is durable, sustainable and conducive for the collective prosperity of the region. 


\section{References}

Alva, M, (1979). 'Janata foreign policy: A critique'. In K.P. Mishra (Ed.), Janata Foreign Policy. New Delhi: Vikash Publishing House. pp: 14

Arbatov, G. (1973). The war of ideas in contemporary international relations: The imperialist doctrine, methods and organisation of foreign political propaganda. Moscow: Progress Publishers. pp: 54-55.

Bains, J.S. (1962). The Farakka barrage: International law aspects'. Modern Review, 112(5): 367.

Bangladesh Observer, (1976). August 22 ( Dhaka).

Bari Shamsul, A.F.M. (1975).' Image and realities of Bangladesh - India relations'. Law and International Affairs, 1(1): 45 .

Chakravarti, S.R. (1978). Bangladesh: Problems of national liberation movement'. In S.R.Chakravarti, Swaroop Rani Dubey, P.C. Mathur and Virendra Narain, Turmoil and Political Change in South AsiaBangladesh, Sri Lanka, India and Pakistan. Jaipur: Aalekh Publishers. pp: 26-27.

Dixit, R.K. (1969). India -Pakistan talks on Farakka Barrage and related matters'. Indian Journal of International Law, 9: 215-16.

Financial Express, (1977). October 3 (New Delhi).

Foreign Affairs Record, (1977). August 8, New Delhi: Ministry of external affairs. Government of India, 23(8): 151.

Indian Recorder, (1997). January 15-2 1, New Delhi: A Weekly of Events and Happenings, 4(3): 2543.

Lok Sabha Debates, (1977). November 14, New Delhi: Lok Sabha Secretariat, 7(1): 298.

Lok Sabha Debates, (1975). April 21, New Delhi: Lok Sabha Secretariat, 2(37): 235.

Lok Sabha Debates, (1977). December 15, New Dehli: Lok Sabha Secretariat, Cols.9,218,232,236 and 268.

Narain, V. (1987). Foreign policy of Bangladesh, 1971-1981: The context of national liberation movement. Jaipur: Aalekh Publishers. pp: 19-25.

Saturday Evening Post, (1976). August 21. Philadelphia: The Curtis Publishing Company.

The Hindu, (1977). November 6, Chennai(India).

Uyangoda, J. (1999). Indo-Bangladesh relations in the 1970s: Bangladesh perspectives'. In Shelton U. Kodikara (Ed.), South Asian Strategic Issues, Sri Lankan Perspectives. New Delhi: Sage Publications. pp: 69.

Vaishnav, T.D. (1975). 'Bangladesh accord on Farakka barrage: Background and implications'. Socialist India, New Delhi: Ministry of External Affairs, 11(2), June 14. 